\title{
Brain tissue oxygenation and cerebral metabolic patterns in focal and diffuse traumatic brain injury
}

\section{Karlis Purins* , Anders Lewén, Lars Hillered, Tim Howells and Per Enblad}

Section of Neurosurgery, Department of Neuroscience, Uppsala University, Uppsala, Sweden

Edited by:

Cameron Bass, Duke University, USA

Reviewed by:

Harvey Pollard, Uniformed Services

University of the Health Sciences,

USA

Bruce G. Lyeth, University of

California Davis, USA

${ }^{*}$ Correspondence:

Karlis Purins, Department of

Neuroscience, Section of

Neurosurgery, Uppsala University

Hospital, Uppsala University, Uppsala

SE-751 85, Sweden

e-mail: karlis.purins@neuro.uu.se
Introduction: Neurointensive care of traumatic brain injury (TBI) patients is currently based on intracranial pressure (ICP) and cerebral perfusion pressure (CPP) targeted protocols. There are reasons to believe that knowledge of brain tissue oxygenation $\left(\mathrm{BtipO}_{2}\right)$ would add information with the potential of improving patient outcome. The aim of this study was to examine $\mathrm{B}_{\mathrm{ti}} \mathrm{PO}_{2}$ and cerebral metabolism using the Neurovent-PTO probe and cerebral microdialysis (MD) in TBI patients.

Methods: Twenty-three severe TBI patients with monitoring of physiological parameters, ICP, CPP, $\mathrm{B}_{\mathrm{ti}} \mathrm{pO}_{2}$, and $\mathrm{MD}$ for biomarkers of energy metabolism (glucose, lactate, and pyruvate) and cellular distress (glutamate, glycerol) were included. Patients were grouped according to injury type (focal/diffuse) and placement of the Neurovent-PTO probe and MD catheter (injured/non-injured hemisphere).

Results: We observed different patterns in $\mathrm{B}_{\mathrm{ti}} \mathrm{pO}_{2}$ and $\mathrm{MD}$ biomarkers in diffuse and focal injury where placement of the probe also influenced the results (ipsilateral/contralateral). In all groups, despite fairly normal levels of ICP and CPP, increased MD levels of glutamate, glycerol, or the L/P ratio were observed at $\mathrm{B}_{\mathrm{ti}} \mathrm{pO}_{2}<5 \mathrm{mmHg}$, indicating increased vulnerability of the brain at this level.

Conclusion: Monitoring of $\mathrm{B}_{\mathrm{ti}} \mathrm{PO}_{2}$ adds important information in addition to traditional ICP and CPP surveillance. Because of the different metabolic responses to very low $\mathrm{B}_{\mathrm{ti}} \mathrm{pO}_{2}$ in the individual patient groups we submit that brain tissue oximetry is a complementary tool rather than an alternative to MD monitoring.

Keywords: brain tissue oxygenation, cerebral metabolism, traumatic brain injury, cerebral ischemia, Neurovent-PTO

\section{INTRODUCTION}

Traumatic brain injury (TBI) remains a major cause of morbidity and mortality $(1,2)$. The management of TBI patients is largely based on intracranial pressure (ICP) and cerebral perfusion pressure (CPP) targeted treatment protocols in order to prevent secondary brain injury and to improve patient outcome (3-7). Cerebral hypoxia and ischemia frequently occur after severe head injury ( $8-10)$ and are major factors causing secondary brain injury $(11,12)$. The occurrence and duration of both entities are negatively correlated with patient outcome (12-14). Multi-modality monitoring of brain tissue oxygenation $\left(\mathrm{B}_{\mathrm{tipO}}\right)$ and cerebral metabolism [e.g., with microdialysis (MD)], provides information for early detection of brain ischemia and could possibly be used to avoid secondary ischemic brain injury (15). In the last decades, extensive amount of research has been done regarding cerebral MD and Clark-type electrochemical $\mathrm{B}_{\mathrm{ti}} \mathrm{PO}_{2}$ monitors (16, 17). Recently, a new fiber optic probe (Neurovent-PTO, NV) was introduced. The device has a great clinical advantage of measuring $\mathrm{B}_{\mathrm{ti}} \mathrm{pO}_{2}$, ICP and brain temperature, simultaneously in a single probe. The clinical experience of the new NV probe is not extensively reported and its potential benefits and limitations needs to be further explored. We also need further knowledge to understand the clinical significance of low $\mathrm{BtipO}_{2}$ levels. We have previously reported the accuracy and stability of the NV probe in vitro (18) and defined the $\mathrm{B}_{\mathrm{tipO}} \mathrm{O}_{2}$ threshold level of ischemia (19) in a standardized pig brain death model (20). To our knowledge, however, there is no published study clarifying the relation of $\mathrm{B}_{\mathrm{tip}} \mathrm{PO}_{2}$ and cerebral metabolism using the new NV probe and cerebral MD in TBI patients. Therefore, the aim of the present study was to examine the cerebral metabolism and cerebral oxygen levels with MD and the new NV probe. The secondary objective was to determine if the response pattern differed depending on type of injury and probe localization.

\section{MATERIALS AND METHODS}

\section{PATIENT MATERIAL AND NEUROINTENSIVE CARE}

This study included 23 patients ( 21 men and 2 women) with severe TBI [including cerebral contusions, diffuse axonal injury (DAI), and extracerebral hematomas]. Mean age was 46 years (range 16-82). All patients were admitted to the neurointensive care unit (NICU) at the Uppsala University Hospital between year 2008 and 2012. Patients with Glasgow Coma Scale of $\leq 8$ (not obeying commands or worse) at the NICU were included. CT scans were performed in all patients. All patients received continuous propofol infusion $1-4 \mathrm{mg} / \mathrm{kg} / \mathrm{h}$ (Propofol-Lipuro ${ }^{\circledR}, \mathrm{B}$ Braun Melsungen AG, Melsungen, Germany) as sedation and 
morphine as analgesia, 1-3 mg intermittently (Morfin Meda ${ }^{\circledR}$, Meda, Sollentuna, Sweden). In all patients, advanced multiparameter neuromonitoring was applied for ICP, CPP, $\mathrm{B}_{\mathrm{ti}} \mathrm{pO}_{2}$, and for cerebral metabolism. The $\mathrm{B}_{\mathrm{ti}} \mathrm{pO}_{2}$ and $\mathrm{MD}$ probes were inserted into the brain as soon as possible after the injury or if a patient deteriorated during the stay in NICU (see below). The treatment was based on ICP and CPP guided protocols (ICP $<20 \mathrm{mmHg}$; CPP $>60 \mathrm{mmHg}$ ) including mild hyperventilation $\left(\mathrm{PaCO}_{2} 30-35 \mathrm{mmHg}\right)$ and head elevation to $30^{\circ}$. Normoventilation was applied as soon as possible. Mass lesions were removed when indicated. High ICP was controlled with hyperventilation, cerebrospinal fluid drainage, barbiturate coma treatment (Pentothal Natrium, Abbott Laboratories, IL, USA), and decompressive craniectomy in an escalated manner.

\section{BRAIN TISSUE OXIMETRY}

A multiparameter Neurovent-PTO ${ }^{\circledR}(\mathrm{NV})$ probe (Raumedic, Munchberg, Germany) for continuous measurements of ICP, $\mathrm{B}_{\mathrm{ti}} \mathrm{pO}_{2}$, and brain temperature was inserted via a burr hole usually in the right frontal lobe. The probes were placed in the left frontal lobe in cases when hemicraniectomy or evacuation of mass lesion was indicated on that side.

\section{MICRODIALYSIS}

A MD catheter [71 High Cut-Off Brain Microdialysis Catheter, M Dialysis AB (formerly CMA Microdialysis) Solna, Sweden] was placed through a separate burr hole in close proximity to the NV probe. The MD catheter was connected to a microinjection pump (106 MD Pump, M Dialysis AB) and perfused with Perfusion Fluid CNS (M Dialysis AB) with a flow rate of $0.3 \mu \mathrm{L} / \mathrm{min}$. The MD samples were collected in $1-\mathrm{h}$ intervals and analyzed for lactate, pyruvate, glucose, glutamate, and glycerol with enzymatic techniques using a bedside analyzer (CMA 600, CMA Microdialysis, Solna, Sweden). The analyzers were automatically calibrated when started as well as every sixth hour using standard calibration solutions from the manufacturer. The total imprecision (coefficient of variation) of the analyzed method was $<10 \%$ for all analytes. In all patients, the first $6 \mathrm{~h}$ of the monitoring time was excluded due to the time needed for the measurement stabilization of the $\mathrm{B}_{\mathrm{ti}} \mathrm{pO}_{2}$ probe. The time periods with barbiturate induced coma were excluded from this study. Bold line on $Y$-axis (Figures 1-3) shows the tentative normal MD values based on Reinstrup et al. (21) and Schulz et al. (22). No correction for relative recovery (extraction efficiency) was made.

\section{CLASSIFICATION OF TYPE OF INJURY AND PROBE PLACEMENT}

The type of injury was classified as focal (extra cerebral hematomas or contusions) or as DAI (Table 1). The patient group with focal lesions was subdivided into two groups based on probe placement: ipsilateral (injured hemisphere) and contralateral (non-injured hemisphere).

\section{DATA COLLECTION AND STATISTICAL METHODS}

Intracranial pressure, $\mathrm{CPP}, \mathrm{MD}, \mathrm{B}_{\mathrm{ti}} \mathrm{pO}_{2}$, and physiological data (heart rate, arterial blood pressure, and peripheral oxygen saturation) were acquired and processed using the Odin software for multi-modality monitoring in the NICU, developed at Uppsala
University and Edinburgh University (23). The trend data were stored in a minute by minute time format. Artifacts, which mainly occurred during the probe recalibration or nursing interventions, were manually removed from the datasets. For the correlative $\mathrm{MD}$ data analysis, the continuous data of $\mathrm{B}_{\mathrm{ti}} \mathrm{pO}_{2}$ and CPP were averaged for 1 -h intervals to match the MD sampling periods taking the 17 min time lag owing to MD catheter dead space into account. Statistical analyses and graphical views were done using Statistica 10.0 for Windows (StatSoft Inc., Tulsa, OK, USA). All data were evaluated for normal distribution and did not meet the assumptions for parametric analysis. Therefore a non-parametric analysis was performed using Kruskal-Wallis analysis of variance (ANOVA) on the full set of evaluated $\mathrm{B}_{\mathrm{ti}} \mathrm{pO}_{2}$ levels and $\mathrm{MD}$ data, and if this was significant, Mann-Whitney $U$ test was used to determine at which levels of $\mathrm{B}_{\mathrm{ti}} \mathrm{PO}_{2}$ there were significant differences (ICP, CPP, and MD). Results were considered significant if $p<0.05$. The data are presented as mean values \pm standard deviation (SD).

\section{ETHICS}

The regional ethical review board in Uppsala has approved this study for human research. Informed consent to participate in the study was obtained for all patients from the nearest kin.

\section{RESULTS}

The $\mathrm{B}_{\mathrm{ti}} \mathrm{pO}_{2}$ and $\mathrm{MD}$ probes were inserted $35 \pm 23 \mathrm{~h}($ mean $\pm \mathrm{SD})$ after the injury. The mean duration of the $\mathrm{B}_{\mathrm{ti}} \mathrm{pO}_{2}$ was $199 \mathrm{~h}$ (range 13-496h). Table 2 and Figures 1-3 summarizes the measurements of ICP, CPP, and MD values (L/P ratio, glutamate, glycerol, glucose) at different $\mathrm{B}_{\mathrm{ti}} \mathrm{pO}_{2}$ levels for all patient groups. The results are presented divided in focal (with ipsilateral or contralateral measurements) and diffuse injury.

\section{FOCAL BRAIN INJURY AND PROBE PLACEMENT ON THE CONTRALATERAL SIDE ICP, CPP, and $\mathrm{B}_{t i} \mathrm{pO}_{2}$}

During monitoring ICP mean values ranged between 12 and $17 \mathrm{mmHg}$ and CPP was in the range $70-90 \mathrm{mmHg}$ at $\mathrm{B}_{\mathrm{ti}} \mathrm{pO}_{2}$ levels of $\geq 10 \mathrm{mmHg}$. When $\mathrm{B}_{\mathrm{ti}} \mathrm{pO}_{2}$ decreased below $10 \mathrm{mmHg}$ ICP was significantly higher $(21.0 \pm 3.2 \mathrm{mmHg})$ and CPP was significantly lower $(61.4 \pm 6.1 \mathrm{mmHg})(p<0.01)$ (Table 2; Figures 1A,B).

\section{MD-glutamate and $\mathrm{B}_{t i} \mathrm{pO}_{2}$}

In this group of patients, $\mathrm{MD}$-glutamate was around 3-9 $\mu \mathrm{mol} / \mathrm{L}$ at $\mathrm{B}_{\mathrm{ti}} \mathrm{pO}_{2}$ levels higher than $5 \mathrm{mmHg}$ (Table 2; Figure 1C). When $\mathrm{B}_{\mathrm{ti}} \mathrm{pO}_{2}$ was below $5 \mathrm{mmHg}$ we observed a significant $(p<0.05)$ increase of MD-glutamate $(15.8 \pm 6.7 \mu \mathrm{mol} / \mathrm{L})$.

\section{MD-glycerol and $\mathrm{B}_{t i p} \mathrm{O}_{2}$}

Similarly, in all patients in this group MD-glycerol was 44$66 \mu \mathrm{mol} / \mathrm{L}$ when $\mathrm{B}_{\mathrm{ti}} \mathrm{pO}_{2}$ was $>10 \mathrm{mmHg}$. $\mathrm{B}_{\mathrm{ti}} \mathrm{pO}_{2} 5-10 \mathrm{mmHg}$ was accompanied with a slight increase of $\mathrm{MD}$-glycerol to $97.5 \pm 134.9 \mu \mathrm{mol} / \mathrm{L}$ (Table 2; Figure 1D). A significant increase of MD-glycerol to $291.3 \pm 144.5(p<0.01)$ was observed at very low oxygen levels $(<5 \mathrm{mmHg})$. 

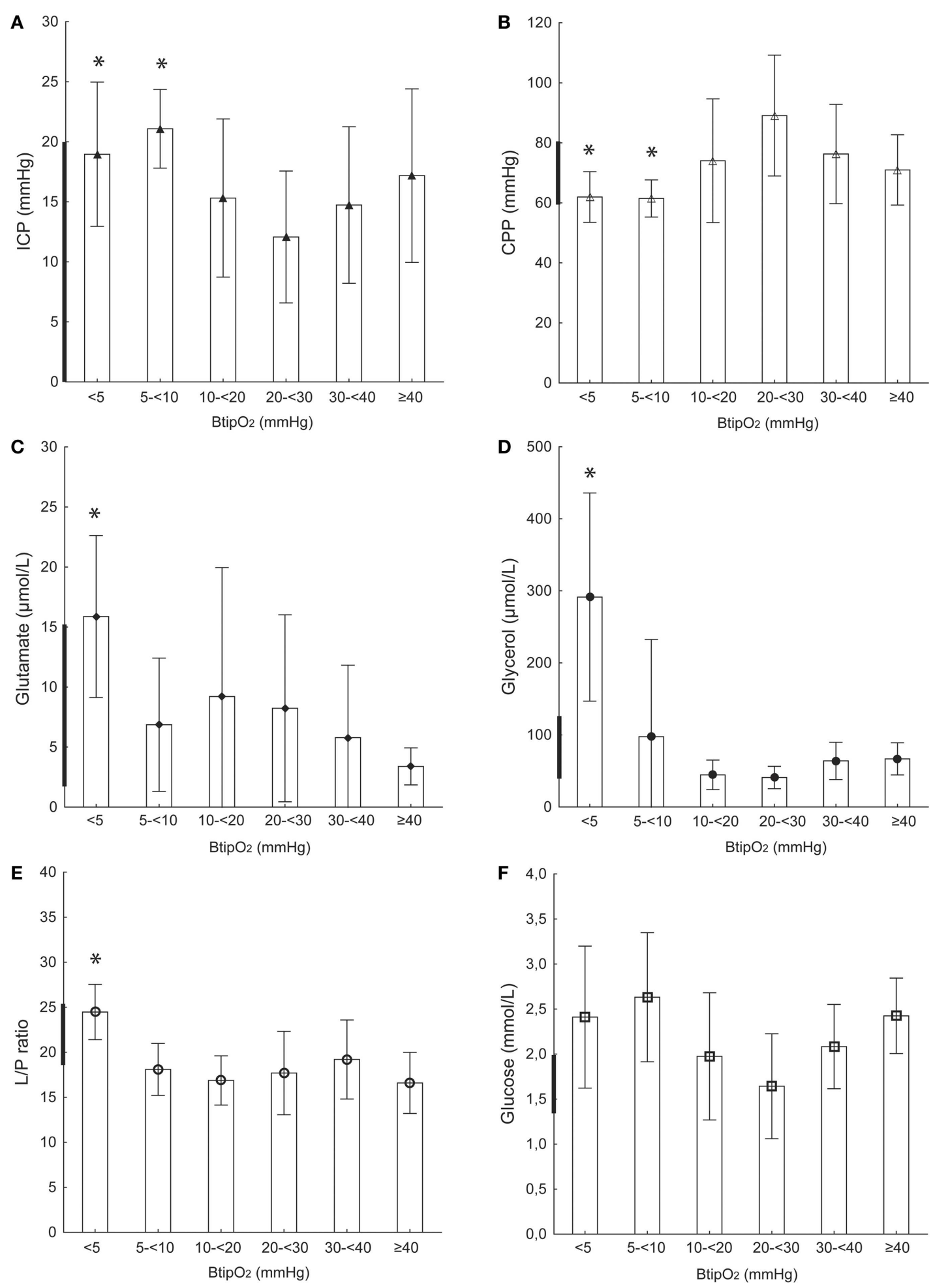

FIGURE 1 | Focal injury and contralateral probe location. ICP (A), CPP (B), glutamate (C), glycerol (D), L/P ratio (E), and glucose (F) at different $\mathrm{B}_{\mathrm{ti}} \mathrm{pO}_{2}$ levels in TBI patients with focal injury and probe (MD and NV) placement on the contralateral side from the injury (non-injured hemisphere). Bold line on

$Y$-axis shows tentative normal MD values based on Reinstrup et al. (21) and Schulz et al. (22). All values are expressed as mean \pm SD. ${ }^{*}$ Denotes a statistically significant difference $(p<0.05)$ compared to each of the higher $\mathrm{B}_{\mathrm{ti}} \mathrm{pO}_{2}$ levels (Mann-Whitney $U$ test). 

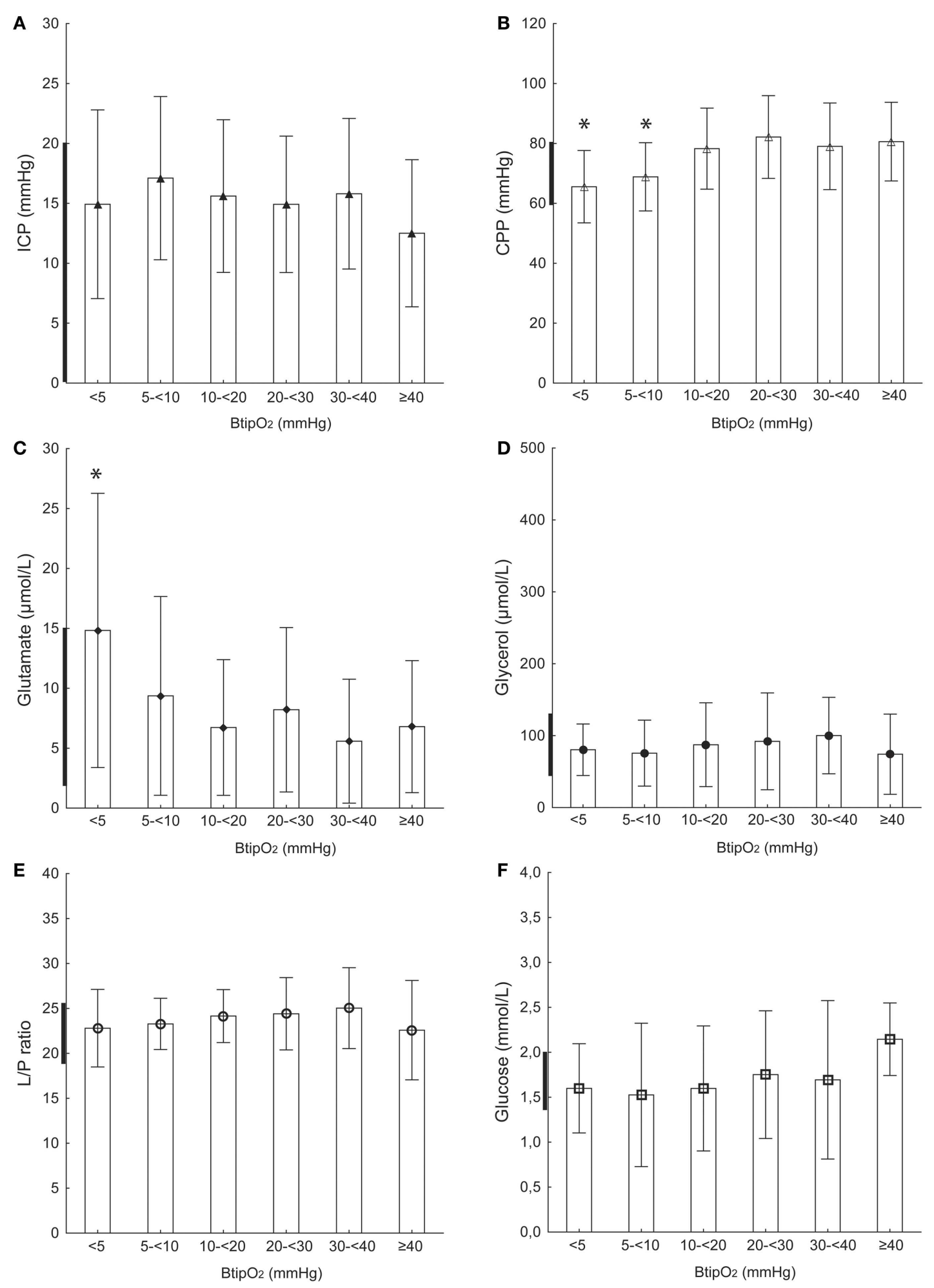

FIGURE 2 | Focal injury and ipsilateral probe location. ICP (A), CPP (B), glutamate (C), glycerol (D), L/P ratio (E), and glucose (F) at different $\mathrm{B}_{\mathrm{ti}} \mathrm{pO}_{2}$ levels in TBI patients with focal injury and probe (MD and NV) placement on the ipsilateral side from the injury (injured hemisphere). Bold line on $Y$-axis

shows tentative normal MD values based on Reinstrup et al. (21) and Schulz et al. (22). All values are expressed as mean \pm SD. * Denotes a statistically significant difference $(p<0.05)$ compared to each of the higher $\mathrm{B}_{\mathrm{ti}} \mathrm{pO}_{2}$ levels (Mann-Whitney $U$ test). 

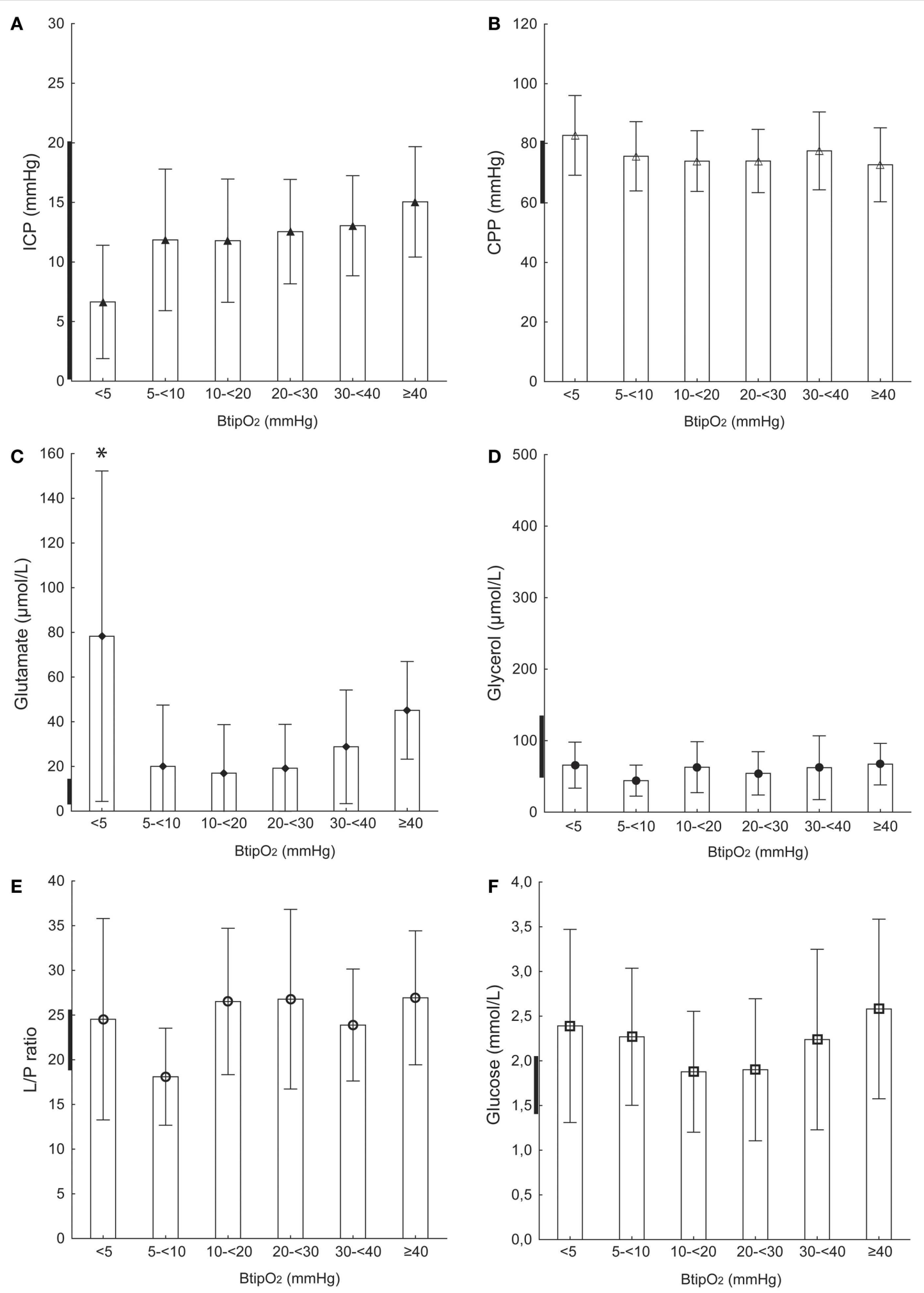

FIGURE 3 | Diffuse injury and probe location on the right side. ICP (A), CPP (B), glutamate (C), glycerol (D), L/P ratio (E), and glucose (F) at different $\mathrm{B}_{\mathrm{t}} \mathrm{PO}_{2}$ levels. TBI patients with diffuse axonal injury and probe (MD and NV) placements in the right frontal hemisphere. Bold line on $Y$-axis shows

tentative normal MD values based on Reinstrup et al. (21) and Schulz et al. (22). All values are expressed as mean $\pm S D$. *Denotes a statistically significant difference $(p<0.05)$ compared to each of the higher $\mathrm{B}_{\mathrm{ti}} \mathrm{pO}_{2}$ levels (Mann-Whitney $U$ test). 
Table 1 |Traumatic brain injury patients investigated: type of injury, NV probe, and MD catheter location.

\begin{tabular}{|c|c|c|c|c|}
\hline Patient no. & $\begin{array}{l}\text { Extra cerebral } \\
\text { hematoma }\end{array}$ & $\begin{array}{l}\text { Cerebral } \\
\text { contusions }\end{array}$ & $\begin{array}{l}\text { Diffuse axonal } \\
\text { injury }\end{array}$ & $\begin{array}{c}\text { Probe } \\
\text { location }\end{array}$ \\
\hline 1 & & $x$ & & Contra \\
\hline 2 & & $x$ & & Contra \\
\hline 3 & & $x$ & & Contra \\
\hline 4 & $x$ & & & Contra \\
\hline 5 & $x$ & & & Contra \\
\hline 6 & $x$ & $x$ & & Contra \\
\hline 7 & $x$ & $x$ & & Ipsi \\
\hline 8 & $x$ & $x$ & & Ipsi \\
\hline 9 & $x$ & & & Ipsi \\
\hline 10 & $x$ & & & Ipsi \\
\hline 11 & $x$ & & & Ipsi \\
\hline 12 & $x$ & & & Ipsi \\
\hline 13 & & $x$ & & Ipsi \\
\hline 14 & & $x$ & & Ipsi \\
\hline 15 & & $x$ & & Ipsi \\
\hline 16 & & $x$ & & Ipsi \\
\hline 17 & & $x$ & & Ipsi \\
\hline 18 & & $x$ & & Ipsi \\
\hline 19 & & & $x$ & Right side \\
\hline 20 & & & $x$ & Right side \\
\hline 21 & & & $x$ & Right side \\
\hline 22 & & & $x$ & Right side \\
\hline 23 & & & $x$ & Right side \\
\hline
\end{tabular}

Ipsi, probe placement frontal in injured hemisphere; contra, probe placement frontal in non-injured hemisphere; right, probe placement in right frontal hemisphere.

\section{$M D-L / P$ ratio and $B_{t i} p_{2}$}

The MD-L/P ratio remained stable and within the normal levels (mean range 16-19) when $\mathrm{B}_{\mathrm{ti}} \mathrm{pO}_{2}$ was $>5 \mathrm{mmHg}$. The MD-L/P ratio was significantly increased to $24.4 \pm 3.0(p<0.01)$ at $\mathrm{B}_{\mathrm{ti}} \mathrm{pO}_{2}$ levels below $5 \mathrm{mmHg}$ (Table 2; Figure 1E).

\section{MD-glucose and $\mathrm{B}_{\text {ti }} \mathrm{pO}_{2}$}

Table 2 and Figure 1F shows the mean MD-glucose concentrations at different $\mathrm{B}_{\mathrm{ti}} \mathrm{pO}_{2}$ levels. We did not observe any significant differences between MD-glucose and $\mathrm{B}_{\mathrm{ti}} \mathrm{pO}_{2}$.

\section{FOCAL BRAIN INJURY AND PROBE PLACEMENT ON THE IPSILATERAL \\ SIDE \\ ICP, $\mathrm{CPP}$, and $\mathrm{B}_{t i} \mathrm{pO}_{2}$}

Table 2 and Figure 2A show the ICP corresponding to different $\mathrm{B}_{\mathrm{ti}} \mathrm{pO}_{2}$ levels in patients with a focal injury and probe placement in the ipsilateral side. Mean ICP was within the normal levels, between 12 and $17 \mathrm{mmHg}$ for all levels of $\mathrm{B}_{\mathrm{ti}} \mathrm{pO}_{2}$. The lowest mean ICP $(12.5 \pm 6.1 \mathrm{mmHg})$ was seen at the highest $\mathrm{B}_{\text {ti }} \mathrm{pO}_{2}$ levels ( $\geq 40 \mathrm{mmHg}$ ), but the differences were not statistically significant.

The mean CPP values with $\mathrm{B}_{\mathrm{ti}} \mathrm{pO}_{2}$ levels below $10 \mathrm{mmHg}$ were significantly $p<0.05)$ lower than mean $\mathrm{CPP}$ at $\mathrm{B}_{\mathrm{ti}} \mathrm{pO}_{2}$ $>10 \mathrm{mmHg}$ (Table 2; Figure 2B). When the $\mathrm{B}_{\mathrm{ti}} \mathrm{pO}_{2}$ levels were between 5 and $10 \mathrm{mmHg}$, the mean CPP was $68.8 \pm 11.4 \mathrm{mmHg}$.
And at the $\mathrm{B}_{\mathrm{ti}} \mathrm{pO}_{2}$ level below $5 \mathrm{mmHg}$ the mean CPP was $65.5 \pm 12.0 \mathrm{mmHg}$. At $\mathrm{B}_{\mathrm{ti}} \mathrm{PO}_{2}$ levels above $10 \mathrm{mmHg}$ the $\mathrm{CPP}$ levels were stable and somewhat high (mean range $78-82 \mathrm{mmHg}$ ).

\section{MD-glutamate and $\mathrm{B}_{t i} \mathrm{pO}_{2}$}

The mean $\mathrm{MD}$-glutamate concentration ranged between 5 and $8 \mu \mathrm{mol} / \mathrm{L}$ at $\mathrm{B}_{\mathrm{ti}} \mathrm{pO}_{2}$ above $10 \mathrm{mmHg}$. A slight but not significant increase in $\mathrm{MD}$-glutamate concentration was observed at levels of $\mathrm{B}_{\mathrm{ti}} \mathrm{pO}_{2} 5-10 \mathrm{mmHg}$ (Table 2; Figure 2C). A drop of $\mathrm{B}_{\mathrm{ti}} \mathrm{pO}_{2}$ below $5 \mathrm{mmHg}$ resulted in a significant increase $(p<0.05)$ of $\mathrm{MD}$-glutamate concentration $(14.8 \pm 11.4 \mu \mathrm{mol} / \mathrm{L})$.

\section{MD-glycerol and MD-L/P ratio}

No differences were seen between $\mathrm{B}_{\mathrm{ti}} \mathrm{PO}_{2}$ levels $\mathrm{MD}$-glycerol. No significant differences observed between $\mathrm{B}_{\mathrm{ti}} \mathrm{pO}_{2}$ and $\mathrm{MD}-\mathrm{L} / \mathrm{P}$ ratio (Table 2; Figures 2D,E).

\section{Mean MD-glucose}

Mean MD-glucose levels were $2.1 \pm 0.4 \mathrm{mmol} / \mathrm{L}$ at the highest $\mathrm{B}_{\mathrm{ti}} \mathrm{pO}_{2}$ pressure and had a stepwise decreasing trend to $1.5 \pm 0.5 \mathrm{mmol} / \mathrm{L}$ at $\mathrm{B}_{\mathrm{ti}} \mathrm{pO}_{2}$ levels $0-5 \mathrm{mmHg}$ (Table 2; Figure 2F). This difference did not reach statistical significance.

\section{DIFFUSE AXONAL INJURY ICP, CPP, and $\mathrm{B}_{t i} \mathrm{pO}_{2}$}

In patients with DAI, mean ICP ranged from 11 to $15 \mathrm{mmHg}$ when $\mathrm{B}_{\mathrm{ti}} \mathrm{PO}_{2}$ levels were $>5 \mathrm{mmHg}$ (Table 2; Figure 3A). At the level of $\mathrm{B}_{\mathrm{ti}} \mathrm{pO}_{2}$ below $5 \mathrm{mmHg}$ the mean ICP was even lower $(6.6 \pm 4.7 \mathrm{mmHg})$ but not statistically significant. At all $\mathrm{B}_{\mathrm{ti}} \mathrm{pO}_{2}$ levels CPP remained within normal levels ranging from 72 to $82 \mathrm{mmHg}$ (Table 2; Figure 3B). No correlation was found between $\mathrm{CPP}$ and $\mathrm{B}_{\mathrm{ti}} \mathrm{pO}_{2}$ levels.

\section{MD-glutamate and $\mathrm{B}_{t i} \mathrm{pO}_{2}$}

MD-glutamate was abnormally high in all patients within this group (Figure 3C). It was significantly higher $(78.2 \pm 73.9 \mu \mathrm{mol} / \mathrm{L}$; $p<0.05$ ) when $\mathrm{B}_{\mathrm{ti}} \mathrm{pO}_{2}$ level was $<5 \mathrm{mmHg}$ (compared to $\mathrm{B}_{\mathrm{ti}} \mathrm{pO}_{2}$ $\geq 5 \mathrm{mmHg}$ ) (Table 2; Figure 3C). At $\mathrm{B}_{\mathrm{ti}} \mathrm{pO}_{2}$ levels of $\geq 5 \mathrm{mmHg}$ the mean $\mathrm{MD}$-glutamate concentrations had no significant correlation with $\mathrm{B}_{\mathrm{ti}} \mathrm{pO}_{2}$ and varied between 17.0 and $45.1 \mu \mathrm{mol} / \mathrm{L}$.

\section{MD-glycerol and $\mathrm{B}_{t i} \mathrm{pO}_{2}$}

Mean MD-glycerol concentration ranged between 44.1 and $67.1 \mu \mathrm{mol} / \mathrm{L}$ and had no significant correlation between different $\mathrm{B}_{\mathrm{ti}} \mathrm{pO}_{2}$ levels (Table 2; Figure 3D).

\section{$M D-L / P$ ratio and $B_{t i} \mathrm{pO}_{2}$}

Table 2 and Figure 3E presents the MD-L/P ratio correlation to different $\mathrm{B}_{\mathrm{ti}} \mathrm{pO}_{2}$ levels. The mean $\mathrm{MD}-\mathrm{L} / \mathrm{P}$ ratio values ranged between 18.1 and 26.9 and had no relation to $\mathrm{B}_{\mathrm{ti}} \mathrm{pO}_{2}$.

\section{MD-glucose and $\mathrm{B}_{t i} \mathrm{pO}_{2}$}

Table 2 and Figure 3F shows the MD-glucose concentrations in relation to different $\mathrm{B}_{\mathrm{ti}} \mathrm{pO}_{2}$ levels. $\mathrm{MD}$-glucose remained normal at all $\mathrm{B}_{\mathrm{ti}} \mathrm{pO}_{2}$ levels and varied between 1.8 and $2.5 \mathrm{mmol}$. Differences in MD-glucose levels did not reach statistical significance. 
Table 2 | Brain tissue oxygenation and MD-dialyzate concentrations at different ICP and CPP levels

\begin{tabular}{|c|c|c|c|c|c|c|c|}
\hline $\mathrm{B}_{\mathrm{ti}} \mathrm{pO}_{2}$ & ICP & CPP & Glutamate & Glycerol & L/P ratio & Glucose & $\begin{array}{l}\text { Sample } \\
\text { size (MD) }\end{array}$ \\
\hline \multicolumn{8}{|c|}{ FOCAL INJURY, CONTRALATERAL $(n=6)$} \\
\hline$<5$ & $18.9 \pm 6.0^{*}$ & $61.9 \pm 8.4^{*}$ & $15.8 \pm 6.7^{*}$ & $291.3 \pm 144.5^{*}$ & $24.4 \pm 3.0^{*}$ & $2.4 \pm 0.7$ & 12 \\
\hline $5 \leq 10$ & $21.0 \pm 3.2^{*}$ & $61.4 \pm 6.1^{*}$ & $6.8 \pm 5.5$ & $97.5 \pm 134.9$ & $18.0 \pm 2.8$ & $2.4 \pm 0.7$ & 20 \\
\hline $10 \leq 20$ & $15.3 \pm 6.5$ & $74.0 \pm 20.6$ & $9.2 \pm 10.7$ & $44.6 \pm 20.5$ & $16.8 \pm 2.7$ & $1.9 \pm 0.7$ & 22 \\
\hline $20 \leq 30$ & $12.0 \pm 5.4$ & $89.0 \pm 20.0$ & $8.2 \pm 7.7$ & $41.0 \pm 15.5$ & $17.6 \pm 4.6$ & $1.6 \pm 0.5$ & 9 \\
\hline $30 \leq 40$ & $14.7 \pm 6.5$ & $76.2 \pm 16.5$ & $5.7 \pm 6.0$ & $63.9 \pm 25.8$ & $19.2 \pm 5.3$ & $2.0 \pm 0.4$ & 262 \\
\hline$\geq 40$ & $17.1 \pm 7.2$ & $71.0 \pm 11.7$ & $3.3 \pm 1.5$ & $66.8 \pm 22.3$ & $16.5 \pm 3.3$ & $2.4 \pm 0.4$ & 228 \\
\hline \multicolumn{8}{|c|}{ FOCAL INJURY, IPSILATERAL (n=12) } \\
\hline$<5$ & $14.9 \pm 7.8$ & $65.5 \pm 12.0^{*}$ & $14.8 \pm 11.4^{*}$ & $80.4 \pm 35.8$ & $22.8 \pm 4.3$ & $1.5 \pm 0.5$ & 30 \\
\hline $5 \leq 10$ & $17.1 \pm 6.8$ & $68.8 \pm 11.4^{*}$ & $9.3 \pm 8.3$ & $75.7 \pm 45.8$ & $23.2 \pm 2.8$ & $1.5 \pm 0.8$ & 48 \\
\hline $10 \leq 20$ & $15.6 \pm 6.3$ & $78.2 \pm 13.5$ & $6.7 \pm 7.1$ & $87.4 \pm 58.3$ & $24.1 \pm 2.9$ & $1.6 \pm 0.7$ & 152 \\
\hline $20 \leq 30$ & $14.9 \pm 5.6$ & $82.1 \pm 13.8$ & $8.2 \pm 6.8$ & $92.1 \pm 67.3$ & $24.4 \pm 4.0$ & $1.7 \pm 0.7$ & 123 \\
\hline $30 \leq 40$ & $15.8 \pm 6.2$ & $79.0 \pm 14.4$ & $5.5 \pm 5.1$ & $100.1 \pm 53.1$ & $25.0 \pm 4.5$ & $1.7 \pm 0.8$ & 244 \\
\hline$\geq 40$ & $12.5 \pm 6.1$ & $80.6 \pm 13.3$ & $6.7 \pm 5.5$ & $74.2 \pm 55.7$ & $22.5 \pm 5.5$ & $2.1 \pm 0.4$ & 85 \\
\hline \multicolumn{8}{|c|}{ DIFFUSE INJURY $(n=5)$} \\
\hline$<5$ & $6.6 \pm 4.7$ & $82.6 \pm 13.3$ & $78.2 \pm 73.9^{*}$ & $65.8 \pm 32.2$ & $24.5 \pm 11.2$ & $2.3 \pm 1.0$ & 14 \\
\hline $5 \leq 10$ & $11.8 \pm 5.9$ & $75.6 \pm 11.6$ & $20.0 \pm 27.4$ & $44.1 \pm 21.7$ & $18.1 \pm 5.4$ & $2.2 \pm 0.7$ & 33 \\
\hline $10 \leq 20$ & $11.8 \pm 5.1$ & $74.0 \pm 10.1$ & $17.0 \pm 21.7$ & $62.9 \pm 35.6$ & $26.5 \pm 8.1$ & $1.8 \pm 0.6$ & 166 \\
\hline $20 \leq 30$ & $12.5 \pm 4.3$ & $74.0 \pm 10.6$ & $19.2 \pm 19.6$ & $54.3 \pm 30.3$ & $26.7 \pm 10.0$ & $1.9 \pm 0.8$ & 270 \\
\hline $30 \leq 40$ & $13.0 \pm 4.2$ & $77.4 \pm 25.4$ & $28.7 \pm 25.4$ & $62.2 \pm 44.5$ & $23.8 \pm 6.2$ & $2.2 \pm 1.0$ & 129 \\
\hline$\geq 40$ & $15.0 \pm 4.6$ & $72.8 \pm 12.4$ & $45.1 \pm 21.8$ & $67.1 \pm 29.0$ & $26.9 \pm 7.4$ & $2.5 \pm 1.0$ & 45 \\
\hline
\end{tabular}

NV probe and MD catheter placement in focal (ipsi- or contra-lateral side) or diffuse axonal injury (right frontal hemisphere). All values are shown as mean \pm SD. *Denotes a statistically significant $(p<0.05)$ difference compared to each of the higher $B_{t i} p O_{2}$ levels (Mann-Whitney $U$ test).

\section{DISCUSSION}

We found that there were different response patterns of $\mathrm{B}_{\mathrm{ti}} \mathrm{pO}_{2}$ and cerebral metabolism depending on the injury type and probe localization which will be discussed in the following sections. Monitoring of $\mathrm{B}_{\mathrm{ti}} \mathrm{pO}_{2}$ in TBI patients is of considerable clinical interest, but the exact threshold level of ischemia has been difficult to establish despite progress on methodological issues. Measurements of $\mathrm{B}_{\mathrm{ti}} \mathrm{PO}_{2}$ using the recently introduced $\mathrm{NV}$ probes have shown to be safe and reliable in several experiments (18-20, 24). In a pre-clinical study, we found that impaired cerebral metabolism determined according to intracerebral MD levels occurred at a $\mathrm{B}_{\mathrm{ti}} \mathrm{pO}_{2}$ level below $10 \mathrm{mmHg}$ using the new NV probe (19). However, to our knowledge, there are no previously published clinical studies using $\mathrm{NV}$ probes together with MD in order to relate cerebral metabolism with critical $\mathrm{B}_{\mathrm{ti}} \mathrm{pO}_{2}$ levels in TBI patients. Therefore, the objective of this investigation was to study $\mathrm{B}_{\mathrm{ti}} \mathrm{pO}_{2}$ and cerebral metabolism at different levels of ICP and CPP in patients with focal and diffuse TBI using the new NV probe.

\section{BRAIN TISSUE OXYGENATION AND INTRACRANIAL DYNAMICS}

Results from our previous pre-clinical study showed a simultaneous decrease of $\mathrm{CPP}$ and $\mathrm{B}_{\mathrm{ti}} \mathrm{pO}_{2}$ during a gradual increase of the ICP (19). There was also a threshold level of impaired cerebral metabolism observed at $\mathrm{B}_{\mathrm{ti}} \mathrm{pO}_{2}<10 \mathrm{mmHg}$. In the present study, we found a significant correlation between low $\mathrm{B}_{\mathrm{ti}} \mathrm{pO}_{2}$ values $(<10 \mathrm{mmHg})$ and increased ICP (mean range $19-21 \mathrm{mmHg}$ ) or decreased CPP (mean $61 \mathrm{mmHg}$ ) in TBI patients with focal injury and the probe placed in the un-injured hemisphere (Figure 1;
Table 2). In patients with focal injury and probe placement in the ipsilateral hemisphere, periods with $\mathrm{B}_{\mathrm{ti}} \mathrm{pO}_{2}<10 \mathrm{mmHg}$ showed significantly lower CPP but there was no relation to ICP (Figure 2; Table 2). In patients with diffuse injury periods with $\mathrm{B}_{\mathrm{ti}} \mathrm{pO}_{2}$ $<5 \mathrm{mmHg}$ tended to be associated with lower ICP but there was no relation to CPP. Thus, the type of injury and probe placement appear to be factors determining the relation between $\mathrm{B}_{\mathrm{ti}} \mathrm{pO}_{2}$ and ICP and CPP, respectively.

\section{L/P RATIO}

The $\mathrm{L} / \mathrm{P}$ ratio is a balance between lactate and pyruvate reflecting the state of cerebral oxidative metabolism and is known as a sensitive marker of cerebral ischemia (25-28). MD-L/P ratio was recently reported to be an independent positive predictor of poor outcome in a large cohort of TBI patients (29). Normal MD-L/P ratio values have been reported previously as approximately $15-20$ $(21,22,30,31)$. Prior studies have used different L/P ratio threshold levels of cerebral ischemia ranging from 25 to $40(17,19,32$, 33). Results from a study of focal TBI revealed that the L/P ratio values are higher in the tissue "at-risk" (ipsilateral side) compared to "normal" tissue (contralateral side) (32). Similarly, in the current study $\mathrm{L} / \mathrm{P}$ ratio seemed to be higher at all $\mathrm{B}_{\mathrm{ti}} \mathrm{pO}_{2}$ levels in TBI patients with focal injury and when probes were placed in the ipsilateral side and also in DAI patients. However, a decrease of $\mathrm{B}_{\mathrm{ti}} \mathrm{pO}_{2}$ to very low levels $(<5 \mathrm{mmHg}$ ) resulted in a significant increase of $\mathrm{L} / \mathrm{P}$ ratio only in patients with focal brain injury and when probes were placed in contralateral side but not in the ipsilateral side (Figures 1E and 2E). Thus, a somewhat provocative 
assumption appeared that in the case of injured tissue in which the $\mathrm{L} / \mathrm{P}$ ratio is already elevated, very low $\mathrm{B}_{\mathrm{ti}} \mathrm{pO}_{2}$ levels do not lead to even higher $\mathrm{L} / \mathrm{P}$ ratios. In relatively un-injured tissue (contralateral side) with a normal $\mathrm{L} / \mathrm{P}$ ratio, however, very low $\mathrm{B}_{\mathrm{tip}} \mathrm{pO}_{2}$ levels do lead to increases in the $\mathrm{L} / \mathrm{P}$ ratio. Further studies with increased number of patients are needed to support this hypothesis.

\section{GLUTAMATE}

Glutamate is the main excitatory transmitter of the central nervous system. In a healthy brain it is actively taken up by neurons and astrocytes after it is released in the synaptic cleft. A significant increase in interstitial glutamate indicates impaired cerebral energy metabolism and impending cell damage (34). Increased brain interstitial MD-glutamate has been reported earlier in TBI (17, 35-40).

MD-glutamate basal concentration in humans ranges between 5 and $15 \mu \mathrm{mol} / \mathrm{L}(21,22)$. A clinical $\mathrm{B}_{\mathrm{ti}} \mathrm{pO}_{2}$ TBI study identified MD-glutamate as the most sensitive and early marker of cerebral ischemia (15). In that study, a significant increase of MDglutamate was observed at $\mathrm{B}_{\mathrm{ti}} \mathrm{pO}_{2}$ level below $10 \mathrm{mmHg}$. A positive correlation has been demonstrated in TBI patients between high levels of MD-glutamate and increased ICP and poor outcome (41). Increased MD-glutamate levels have also been reported in TBI patients mostly with CPP below $70 \mathrm{mmHg}$ (37). In that study, the authors also found patients with high MD-glutamate and CPP above $70 \mathrm{mmHg}$. In addition, they did not specify the location of the probe and the type of the injury which could explain potentially different pathophysiological processes. The effect of MD catheter location has also been studied in TBI patients with focal injury, and higher MD-glutamate concentrations were found in the most injured brain hemisphere (42).

In the present study in patients with focal TBI, we observed that $\mathrm{MD}$-glutamate increased significantly irrespective of the placement of the probe when $\mathrm{B}_{\mathrm{ti}} \mathrm{pO}_{2}$ decreased to extremely low $(<5 \mathrm{mmHg})$ levels. DAI patients appeared to have higher MDglutamate levels than patients with a focal injury, but even in this group a decrease of $\mathrm{B}_{\mathrm{ti}} \mathrm{pO}_{2}$ to $<5 \mathrm{mmHg}$ was associated with significantly higher glutamate levels (Figure 3C), illustrating the energy dependence of the astrocytic glutamate-glutamine cycle capacity to clear interstitial glutamate (34). The overall high MD-glutamate concentration observed in diffuse injury could be explained by massive neuronal cell damage occurring in DAI and most likely originating from intracellular stores that leak into the extra-cellular space as the neuronal membrane loses its structural integrity (43).

\section{GLYCEROL}

Glycerol is one of the end products in cell membrane phospholipid degradation. It can be used as a marker of phospholipid degradation in cerebral ischemia (44). Experimental and clinical studies have shown significant increases of MD-glycerol during cerebral ischemia (44-46). Normal cerebral MD-glycerol levels have been reported previously from patients during wakefulness, anesthesia, and neurosurgical procedures (21). Clausen et al. reported increased glycerol levels when $\mathrm{B}_{\mathrm{ti}} \mathrm{pO}_{2}$ decreased below $10 \mathrm{mmHg}$ (47). We have recently shown in a pre-clinical study that the interstitial MD-glycerol concentration increases when CPP or $\mathrm{B}_{\mathrm{ti}} \mathrm{pO}_{2}$ decrease (19). In the present study under similar conditions (focal TBI on the contralateral side), periods with low $\mathrm{CPP}$ and $\mathrm{B}_{\mathrm{ti}} \mathrm{pO}_{2}$ significantly correlated with increased MD-glycerol levels. However, we did not see any correlation of $\mathrm{B}_{\mathrm{ti}} \mathrm{pO}_{2}$ and MD-glycerol levels in the more injured hemisphere (ipsi) or in DAI patients. These results are similar to those for $\mathrm{L} / \mathrm{P}$ ratio in that relatively un-injured tissue seemed to be more sensitive to decreased $\mathrm{B}_{\mathrm{ti}} \mathrm{pO}_{2}$ than injured tissue. It is unclear which factors are responsible for the heterogeneity of the MD-glycerol levels between hemispheres in focal TBI and between focal TBI and DAI patients. Based on recent validation data implicating $\mathrm{MD}$-glycerol as a biomarker of oxidative stress we submit that this may be an important additional factor to consider (48).

\section{CLINICAL ASPECTS}

In a clinical situation $\mathrm{B}_{\mathrm{ti}} \mathrm{PO}_{2}$ may be influenced by parameters such as cerebral metabolism, cerebral blood flow, oxygen diffusion, sedation, hyperventilation, low inspired oxygen, ICP and CPP changes, age, trauma severity, and other traumatic changes in the cellular environment. It is obvious that the interpretation of $\mathrm{B}_{\mathrm{ti}} \mathrm{pO}_{2}$ needs to be carefully considered, preferably together with other parameters such as MD and cerebral blood flow assessments. The thresholds may vary in different patients. However, in all three patient groups analyzed very low $\mathrm{B}_{\mathrm{ti}} \mathrm{pO}_{2}$ levels $<5 \mathrm{mmHg}$ were accompanied by increases in either the $\mathrm{MD}-\mathrm{L} / \mathrm{P}$ ratio, $\mathrm{MD}$ glutamate or MD-glycerol, indicating an increased vulnerability of the brain at this level of oxygen despite fairly normal levels of ICP and CPP. Thus, $\mathrm{B}_{\mathrm{ti}} \mathrm{pO}_{2}$ monitoring adds valuable information about the brain vulnerability not disclosed by routine ICP and CPP surveillance. However, very low $\mathrm{B}_{\mathrm{ti}} \mathrm{pO}_{2}$ levels $<5 \mathrm{mmHg}$ were associated with different response patterns for biomarkers of energy metabolism (MD-glucose, $\mathrm{MD}-\mathrm{L} / \mathrm{P}$ ratio) and cellular distress (MD-glutamate, $\mathrm{MD}$-glycerol) suggesting that $\mathrm{B}_{\mathrm{ti}} \mathrm{PO}_{2}$ monitoring is a complement to $\mathrm{MD}$ monitoring rather than an alternative.

\section{LIMITATIONS OF THE STUDY AND FUTURE DIRECTION OF RESEARCH}

A number of limitations of this study should be recognized. First, the limited number of patients did not permit multivariate statistical analysis comparing other factors such as carbon dioxide partial pressure $\left(\mathrm{pCO}_{2}\right)$, sedation, and inspired oxygen concentration. Second, we could not address the dependence of oxygen metabolism, oxygen extraction fraction, and cerebral blood flow including auto-regulation. Third, brain temperature data were not analyzed in this paper for technical reasons. Future TBI studies are needed to explore how episodes of low or high $\mathrm{B}_{\mathrm{ti}} \mathrm{PO}_{2}$ levels are correlated with hyperventilation, sedation, changes in inspired oxygen concentration, blood pressure, cerebral auto-regulation, cerebral blood flow, and oxygen metabolism as well as outcome. To gather a sufficient number of patients a multi-center study may be needed.

\section{CONCLUSION}

We observed different patterns of changes in $\mathrm{B}_{\mathrm{ti}} \mathrm{pO}_{2}$ and cerebral MD biomarker patterns in focal and diffuse TBI patients. The placement of the probe in focal injury did also influence the results. However, despite fairly normal levels of ICP and CPP in all 
groups, increased cerebral MD levels of glutamate, glycerol, or the lactate/pyruvate ratio were observed at $\mathrm{B}_{\mathrm{ti}} \mathrm{pO}_{2}<5 \mathrm{mmHg}$, indicating increased vulnerability of the brain at this critical level of tissue oxygenation.

\section{ACKNOWLEDGMENTS}

Inger Ståhl Myllyaho is acknowledged for excellent laboratory assistance. Financial support: the study was supported by The Swedish Research Council, Swedish Brain Foundation, Selander Foundation, Åhlén Foundation, and funds from the Uppsala University Hospital.

\section{REFERENCES}

1. Thurman DJ, Alverson C, Dunn KA, Guerrero J, Sniezek JE. Traumatic brain injury in the United States: a public health perspective. J Head Trauma Rehabil (1999) 14(6):602-15. doi:10.1097/00001199-199912000-00009

2. Sundstrom T, Sollid S, Wentzel-Larsen T, Wester K. Head injury mortality in the Nordic countries. J Neurotrauma (2007) 24(1):147-53. doi:10.1089/neu.2006. 0099

3. Bratton SL, Chestnut RM, Ghajar J, McConnell Hammond FF, Harris OA, Hartl R, et al. Guidelines for the management of severe traumatic brain injury. VI. Indications for intracranial pressure monitoring. J Neurotrauma (2007) 24(Suppl 1):S37-44. doi:10.1089/neu.2007.9990

4. Maas AI, Dearden M, Teasdale GM, Braakman R, Cohadon F, Iannotti F, et al. EBIC-guidelines for management of severe head injury in adults. European Brain Injury Consortium. Acta Neurochir (Wien) (1997) 139(4):286-94. doi:10.1007/BF01808823

5. Rosner MJ, Daughton S. Cerebral perfusion pressure management in head injury. J Trauma (1990) 30(8):933-40. doi:10.1097/00005373-199008000-00001 discussion 40-1,

6. Rosner MJ, Rosner SD, Johnson AH. Cerebral perfusion pressure: management protocol and clinical results. J Neurosurg (1995) 83(6):949-62. doi:10.3171/jns. 1995.83.6.0949

7. Brain Trauma Foundation AAoNS, Congress of Neurological Surgeons. Guidelines for the management of severe traumatic brain injury. J Neurotrauma (2007) 24(Suppl 1):S1-106. doi:10.1089/neu.2007.9999

8. Graham DI, Adams JH, Doyle D. Ischaemic brain damage in fatal non-missile head injuries. J Neurol Sci (1978) 39(2-3):213-34. doi:10.1016/0022-510X(78) 90124-7

9. Graham DI, Ford I, Adams JH, Doyle D, Teasdale GM, Lawrence AE, et al. Ischaemic brain damage is still common in fatal non-missile head injury. J Neurol Neurosurg Psychiatry (1989) 52(3):346-50. doi:10.1136/jnnp.52.3.346

10. Stocchetti N, Furlan A, Volta F. Hypoxemia and arterial hypotension at the accident scene in head injury. J Trauma (1996) 40(5):764-7. doi:10.1097/00005373199605000-00014

11. Bouma GJ, Muizelaar JP, Choi SC, Newlon PG, Young HF. Cerebral circulation and metabolism after severe traumatic brain injury: the elusive role of ischemia. J Neurosurg (1991) 75(5):685-93. doi:10.3171/jns.1991.75.5.0685

12. Chesnut RM, Marshall LF, Klauber MR, Blunt BA, Baldwin N, Eisenberg HM, et al. The role of secondary brain injury in determining outcome from severe head injury. J Trauma (1993) 34(2):216-22. doi:10.1097/00005373-19930200000006

13. Bardt TF, Unterberg AW, Hartl R, Kiening KL, Schneider GH, Lanksch WR. Monitoring of brain tissue PO2 in traumatic brain injury: effect of cerebral hypoxia on outcome. Acta Neurochir Suppl (1998) 71:153-6.

14. Dings J, Jager A, Meixensberger J, Roosen K. Brain tissue pO2 and outcome after severe head injury. Neurol Res (1998) 20(Suppl 1):S71-5.

15. Sarrafzadeh AS, Sakowitz OW, Callsen TA, Lanksch WR, Unterberg AW. Bedside microdialysis for early detection of cerebral hypoxia in traumatic brain injury. Neurosurg Focus (2000) 9(5):e2.

16. Beynon C, Kiening KL, Orakcioglu B, Unterberg AW, Sakowitz OW. Brain tissue oxygen monitoring and hyperoxic treatment in patients with traumatic brain injury. J Neurotrauma (2012) 29(12):2109-23. doi:10.1089/neu.2012.2365

17. Hillered L, Vespa PM, Hovda DA. Translational neurochemical research in acute human brain injury: the current status and potential future for cerebral microdialysis. J Neurotrauma (2005) 22(1):3-41. doi:10.1089/neu.2005.22.3
18. Purins K, Enblad P, Sandhagen B, Lewen A. Brain tissue oxygen monitoring: a study of in vitro accuracy and stability of Neurovent-PTO and Licox sensors. Acta Neurochir (Wien) (2010) 152(4):681-8. doi:10.1007/s00701-0090532- $\mathrm{x}$

19. Purins K, Enblad P, Wiklund L, Lewen A. Brain tissue oxygenation and cerebral perfusion pressure thresholds of ischemia in a standardized pig brain death model. Neurocrit Care (2012) 16(3):462-9. doi:10.1007/s12028-012-9675-3

20. Purins K, Sedigh A, Molnar C, Jansson L, Korsgren O, Lorant T, et al. Standardized experimental brain death model for studies of intracranial dynamics, organ preservation, and organ transplantation in the pig. Crit Care Med (2011) 39(3):512-7. doi:10.1097/CCM.0b013e318206b824

21. Reinstrup P, Stahl N, Mellergard P, Uski T, Ungerstedt U, Nordstrom CH Intracerebral microdialysis in clinical practice: baseline values for chemical markers during wakefulness, anesthesia, and neurosurgery. Neurosurgery (2000) 47(3):701-9. doi:10.1227/00006123-200009000-00035 discussion 9-10,

22. Schulz MK, Wang LP, Tange M, Bjerre P. Cerebral microdialysis monitoring: determination of normal and ischemic cerebral metabolisms in patients with aneurysmal subarachnoid hemorrhage. J Neurosurg (2000) 93(5):808-14. doi:10.3171/jns.2000.93.5.0808

23. Howells T, Elf K, Jones PA, Ronne-Engstrom E, Piper I, Nilsson P, et al. Pressure reactivity as a guide in the treatment of cerebral perfusion pressure in patients with brain trauma. J Neurosurg (2005) 102(2):311-7. doi:10.3171/jns.2005.102. 2.0311

24. Orakcioglu B, Sakowitz OW, Neumann JO, Kentar MM, Unterberg A, Kiening KL. Evaluation of a novel brain tissue oxygenation probe in an experimental swine model. Neurosurgery (2010) 67(6):1716-22. doi:10.1227/NEU. 0b013e3181f9bb5b discussion 22-3,

25. Enblad P, Valtysson J, Andersson J, Lilja A, Valind S, Antoni G, et al. Simultaneous intracerebral microdialysis and positron emission tomography in the detection of ischemia in patients with subarachnoid hemorrhage. J Cereb Blood Flow Metab (1996) 16(4):637-44. doi:10.1097/00004647-199607000-00014

26. Enblad P, Frykholm P, Valtysson J, Silander HC, Andersson J, Fasth KJ, et al. Middle cerebral artery occlusion and reperfusion in primates monitored by microdialysis and sequential positron emission tomography. Stroke (2001) 32(7):1574-80. doi:10.1161/01.STR.32.7.1574

27. Nilsson OG, Brandt L, Ungerstedt U, Saveland H. Bedside detection of brain ischemia using intracerebral microdialysis: subarachnoid hemorrhage and delayed ischemic deterioration. Neurosurgery (1999) 45(5):1176-84. doi:10. 1097/00006123-199911000-00032 discussion 84-5,

28. Sarrafzadeh AS, Haux D, Ludemann L, Amthauer H, Plotkin M, Kuchler I, et al. Cerebral ischemia in aneurysmal subarachnoid hemorrhage: a correlative microdialysis-PET study. Stroke (2004) 35(3):638-43. doi:10.1161/01.STR. 0000116101.66624.F1

29. Timofeev I, Carpenter KL, Nortje J, Al-Rawi PG, O’Connell MT, Czosnyka M, et al. Cerebral extracellular chemistry and outcome following traumatic brain injury: a microdialysis study of 223 patients. Brain (2011) 134(Pt 2):484-94. doi:10.1093/brain/awq353

30. Hutchinson PJ, Gupta AK, Fryer TF, Al-Rawi PG, Chatfield DA, Coles JP, et al. Correlation between cerebral blood flow, substrate delivery, and metabolism in head injury: a combined microdialysis and triple oxygen positron emission tomography study. J Cereb Blood Flow Metab (2002) 22(6):735-45. doi:10.1097/00004647-200206000-00012

31. Persson L, Valtysson J, Enblad P, Warme PE, Cesarini K, Lewen A, et al. Neurochemical monitoring using intracerebral microdialysis in patients with subarachnoid hemorrhage. J Neurosurg (1996) 84(4):606-16. doi:10.3171/jns.1996. 84.4 .0606

32. Nordstrom CH, Reinstrup P, Xu W, Gardenfors A, Ungerstedt U. Assessment of the lower limit for cerebral perfusion pressure in severe head injuries by bedside monitoring of regional energy metabolism. Anesthesiology (2003) 98(4):809-14. doi:10.1097/00000542-200304000-00004

33. Vespa PM, O’Phelan K, McArthur D, Miller C, Eliseo M, Hirt D, et al. Pericontusional brain tissue exhibits persistent elevation of lactate/pyruvate ratio independent of cerebral perfusion pressure. Crit Care Med (2007) 35(4):1153-60. doi:10.1097/01.CCM.0000259466.66310.4F

34. Samuelsson C, Hillered L, Zetterling M, Enblad P, Hesselager G, Ryttlefors M, et al. Cerebral glutamine and glutamate levels in relation to compromised energy metabolism: a microdialysis study in subarachnoid hemorrhage patients. J Cereb Blood Flow Metab (2007) 27(7):1309-17. doi:10.1038/sj.jcbfm.9600433 
35. Chamoun R, Suki D, Gopinath SP, Goodman JC, Robertson C. Role of extracellular glutamate measured by cerebral microdialysis in severe traumatic brain injury. J Neurosurg (2010) 113(3):564-70. doi:10.3171/2009.12.JNS09689

36. Persson L, Hillered L. Chemical monitoring of neurosurgical intensive care patients using intracerebral microdialysis. J Neurosurg (1992) 76(1):72-80. doi:10.3171/jns.1992.76.1.0072

37. Vespa P, Prins M, Ronne-Engstrom E, Caron M, Shalmon E, Hovda DA, et al. Increase in extracellular glutamate caused by reduced cerebral perfusion pressure and seizures after human traumatic brain injury: a microdialysis study. J Neurosurg (1998) 89(6):971-82. doi:10.3171/jns.1998.89.6.0971

38. Bullock R, Fujisawa $\mathrm{H}$. The role of glutamate antagonists for the treatment of CNS injury. J Neurotrauma (1992) 9(Suppl 2):S443-62.

39. Katayama Y, Becker DP, Tamura T, Hovda DA. Massive increases in extracellular potassium and the indiscriminate release of glutamate following concussive brain injury. J Neurosurg (1990) 73(6):889-900. doi:10.3171/jns.1990.73.6. 0889

40. Nilsson P, Hillered L, Ponten U, Ungerstedt U. Changes in cortical extracellular levels of energy-related metabolites and amino acids following concussive brain injury in rats. J Cereb Blood Flow Metab (1990) 10(5):631-7. doi:10.1038/jcbfm.1990.115

41. Bullock R, Zauner A, Woodward JJ, Myseros J, Choi SC, Ward JD, et al. Factors affecting excitatory amino acid release following severe human head injury. J Neurosurg (1998) 89(4):507-18. doi:10.3171/jns.1998.89.4.0507

42. Engstrom M, Polito A, Reinstrup P, Romner B, Ryding E, Ungerstedt U, et al. Intracerebral microdialysis in severe brain trauma: the importance of catheter location. J Neurosurg (2005) 102(3):460-9. doi:10.3171/jns.2005.102.3.0460

43. Katayama Y, Kawamata T, Tamura T, Hovda DA, Becker DP, Tsubokawa T. Calcium-dependent glutamate release concomitant with massive potassium flux during cerebral ischemia in vivo. Brain Res (1991) 558(1):136-40. doi:10.1016/0006-8993(91)90730-J

44. Hillered L, Valtysson J, Enblad P, Persson L. Interstitial glycerol as a marker for membrane phospholipid degradation in the acutely injured human brain. J Neurol Neurosurg Psychiatry (1998) 64(4):486-91. doi:10.1136/jnnp.64.4.486
45. Frykholm P, Hillered L, Langstrom B, Persson L, Valtysson J, Watanabe Y, et al. Increase of interstitial glycerol reflects the degree of ischaemic brain damage: a PET and microdialysis study in a middle cerebral artery occlusionreperfusion primate model. J Neurol Neurosurg Psychiatry (2001) 71(4):455-61. doi:10.1136/jnnp.71.4.455

46. Marklund N, Salci K, Lewen A, Hillered L. Glycerol as a marker for posttraumatic membrane phospholipid degradation in rat brain. Neuroreport (1997) 8(6):1457-61. doi:10.1097/00001756-199704140-00026

47. Clausen T, Alves OL, Reinert M, Doppenberg E, Zauner A, Bullock R. Association between elevated brain tissue glycerol levels and poor outcome following severe traumatic brain injury. J Neurosurg (2005) 103(2):233-8. doi:10.3171/ jns.2005.103.2.0233

48. Clausen F, Marklund N, Lewen A, Enblad P, Basu S, Hillered L. Interstitial $\mathrm{F}$ (2)-isoprostane 8-iso-PGF(2alpha) as a biomarker of oxidative stress after severe human traumatic brain injury. J Neurotrauma (2012) 29(5):766-75. doi:10.1089/neu.2011.1754

Conflict of Interest Statement: The authors declare that the research was conducted in the absence of any commercial or financial relationships that could be construed as a potential conflict of interest.

Received: 10 March 2014; accepted: 15 April 2014; published online: 01 May 2014. Citation: Purins K, Lewén A, Hillered L, Howells T and Enblad P (2014) Brain tissue oxygenation and cerebral metabolic patterns in focal and diffuse traumatic brain injury. Front. Neurol. 5:64. doi: 10.3389/fneur.2014.00064

This article was submitted to Neurotrauma, a section of the journal Frontiers in Neurology.

Copyright (c) 2014 Purins, Lewén, Hillered, Howells and Enblad. This is an open-access article distributed under the terms of the Creative Commons Attribution License (CC BY). The use, distribution or reproduction in other forums is permitted, provided the original author(s) or licensor are credited and that the original publication in this journal is cited, in accordance with accepted academic practice. No use, distribution or reproduction is permitted which does not comply with these terms. 